\title{
THE IMPACTS OF THE USE OF GADGETS ON THE DEVELOPMENT OF CHILDREN 3-6 YEARS OF AGE
}

${ }_{1}^{1}$ Enny Fitriahadi, ${ }^{2}$ Venaswari Hanna Tyastiti

Midwifery Program, Universitas 'Aisyiyah Yogyakarta, Yogyakarta, Indonesia

\section{INFORMASI ARTIKEL:}

\section{Riwayat Artikel:}

Tanggal diterima: Maret 2020

Tanggal di revisi: Maret 2020

Tanggal di Publikasi: April 2020

Key Word : gadgets, children's

development, parents' control, impacts

\begin{abstract}
A B S T R A C T
Gadgets can indeed distract someone with the fun they get from these gadgets. Children are also affected by the latest technology because of the many applications offered in the gadgets, for example smartphones, that can change their habits to be immersed in a fun program in the gadgets they hold. Therefore, this study aims to determine the magnitude of the impact that can be produced by the use of gadgets on children, especially those aged 3-6 years. This research was conducted in a health post for children with a total of 26 respondents from the parents of the children studied. The instrument used was a questionnaire and a prescreening developmental format with Spearman rank for the statistical test. The result showed that there was a relationship between the use of gadgets and the development of children with a $p$ value of 0.000 . Parents' control over the use of gadgets among children is needed to protect children from addiction that gives adverse impacts.
\end{abstract}

\section{INTRODUCTION}

The development of technology and communication such as gadgets today is very rapid (Abdel-Aziz, Abdel-Salam, \& El-Sayad, 2016). In addition to that, the development of technology and communication has a huge impact on education (Zolfaghari \& Kargozari, 2011), including the education of early childhood (Blackwell, Lauricella, \& Wartella, 2014)). In fact, technology has increasingly been used in the children life, without exception the negative aspects that might be involved in it (Alghamdi, 2016). It is widely known that children are in the golden age and, in this phase, they love to imitate whatever they see, including what is displayed in the gadget, like a cellphone (Phonkhao, \& Laila, 2012). It has been studied that the introduction of gadgets too early in children can have not only the positive impacts but also the negative ones (Sundus, 2018; Hosokawa \& Katsura, 2018). Gadgets used as a tool for learning in children will have positive impacts such as increasing children's creativity and thinking process. However, when children are busy drowning their time in playing with their gadgets without knowing the time, the

\footnotetext{
*Korespondensi: ennyfitriahadi@unisayogya.ac.id
}

negative impacts of using this gadget will be felt. Therefore, the roles of parents play a very important part, such as providing good control over what the children do with their gadgets by giving strict rules when they can have the gadgets with them.

Children's tendencies towards smartphones influence children's behavior and emotional intelligence. Children with a vulnerable age of 2-4 years tend to use smartphones for 2 hours per day (Cho \& Lee, 2017). This shows that today's children in the use of smart phones can start at an early age (Chiu, 2015). Due to competition between network providers, the use of internet in smartphone is becoming affordable so that its increased use is not only in adults or adolescents, but also in children. Lack of control from parents to children to use the gadget, including smartphones, will certainly show a negative impact on children, particularly an impact on daily social behavior and emotional intelligence of children.

With the increasingly widespread negative impacts of smartphones that are not accompanied by parental control, the positive impacts of smartphones may not be seen clearly. Therefore, as parents, directing the use of smartphones by giving a logical understanding to their children is very 
important. This will make early childhood education with the use of technology easier to be carried out so that early childhood development will well be directed. This study was intended to reveal the impacts that might occur in the use of gadgets in relation to children's development, particularly those in the range age between three to six years old.

\section{METHOD}

This quantitative research used a correlation analytic design and a cross-sectional approach. The sampling technique was total sampling with a total of 29 respondents. The location of this research was in a health post for routinely carried out once a month. The instrument used was a questionnaire and a prescreening developmental format. Spearman rank was used for the statistical test.

\section{RESULT AND DISCUSSION}

The examination of the child's growth and development was done to find out the children's development that was not in accordance with their age, which would be intervened by providing education to parents and even referring them to the health center.

Table 1. Frequency Distribution on Children's Characteristics

\begin{tabular}{clcc}
\hline No. & Category & $\begin{array}{c}\text { Frequency } \\
(f)\end{array}$ & $\%$ \\
\hline 1 & Age (in month) & & \\
& & 21 & 72.4 \\
& $36-45$ & 3 & 10.3 \\
& $46-55$ & 5 & 17.3 \\
& $56-65$ & & \\
& & 13 & 44.8 \\
2 & Sex & 16 & 55.2 \\
& Male & 29 & 100 \\
& Female & & \\
& Total responden & & \\
\hline
\end{tabular}

Based on table 1, of the 29 total respondents, the age of the children was dominated at the age of 36-45 months by 21 children (72.2\%) and there were more female by 16 children $(55,2 \%)$ than male children.

Table 2. Frequency Distribution on Parents' Characteristics

\begin{tabular}{cccc}
\hline No & Category & $\begin{array}{c}\text { Frequency } \\
(f)\end{array}$ & $\mathbf{\%}$ \\
\hline 1 & Education & & \\
& Elementary & 2 & 6.9 \\
& Junior High & 0 & 0 \\
& Senior High & 19 & 65.5 \\
& Univ. & 8 & 27.6 \\
2 & Employment & & \\
& Housemaker & 20 & 69 \\
& Private & 4 & 13,8 \\
& Civil servant & 2 & 6.9 \\
& Others & 3 & 10.3 \\
& Total & 29 & 100 \\
& & &
\end{tabular}

The most recent education of the respondents' parents was the high school level by 19 people $(65.5 \%)$ and most of the parents were a homemaker by 20 people (69\%) (Table 2$)$.

\section{Table 3. Frequency Distribution on Use of Gadget in This Study}

\begin{tabular}{cccc}
\hline No. & Category & $\begin{array}{c}\text { Frequency } \\
(\boldsymbol{f})\end{array}$ & $\%$ \\
\hline 1 & Normal & 27 & 93.1 \\
2 & Not & 2 & 6.9 \\
& normal & 29 & 100 \\
\hline
\end{tabular}

Table 3 shows the results of the gadget use based on the questionnaire given filled in by the parents while at the health post for children with the normal results by 27 children (93.1\%). 
Table 4. The Prescreening Developmental Results

\begin{tabular}{cccc}
\hline No. & Category & $\begin{array}{c}\text { Frequency } \\
(\boldsymbol{f})\end{array}$ & \% \\
\hline 1 & Fit & 28 & 96.6 \\
2 & Not fit & 1 & 3.4 \\
& Total & 29 & 100 \\
\hline
\end{tabular}

The development screening shows that the results of interpretation were appropriate by 28 children $(96.6 \%)$.

Table 5. Cross Tabulation on the Use of Gadget with Children's Development

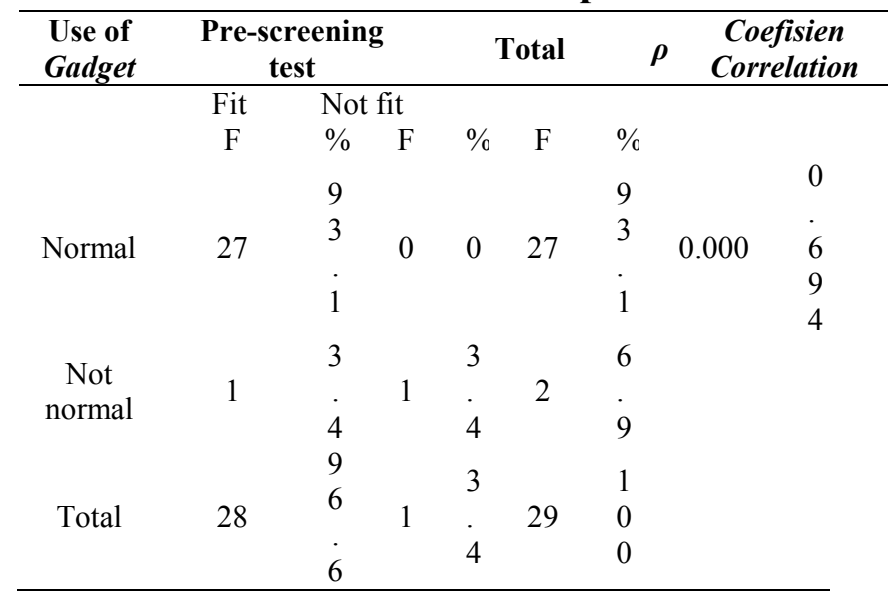

The statistical test using the Spearman Rank with $\alpha(0.05)$ shows a result of a $0.000 \mathrm{p}$ value, which was smaller than the significant level (p-value $<0.05$ ) so that it is said that there was a relationship between the use of gadgets and the development of children with a strong close power.

Based on the analysis, the normal use of gadgets was gained by 27 respondents $(93.1 \%)$ and the remaining 2 respondents were not normal (6.9\%). The normal category for gadget use in children can be seen from the duration of use and the impact caused by the gadget. It is known that exposure to gadgets for too long has a negative impact on children, for example becoming indifferent to the environment and leaving their obligations to learn. The prescreening developmental results show that 28 respondents $(96.6 \%)$ were in accordance with the age of their development. As information, children's development is a critical period where necessary stimuli are needed, for example, receiving attention. Children's development will be optimal if social interaction is attempted in accordance with their needs at various stages of development. In contrast, the environment that does not support will hinder the development, for example, the parents that allow their children to use gadgets not in appropriate time.

The satisfaction that arises from using a gadget like smartphones can foster confidence in children that they are able to complete their tasks well and want to continue with a higher level when dealing with games. The negative impact emerges when children are addicted to playing gadgets. This can be analyzed from the results of the gadget use questionnaire that is not normal because parents do not know the time limit that should be applied to children, so there are children who spend too much time playing gadgets, especially when they are not with their parents. Unlike television, games offer the player the opportunity to become involved in and vicariously act out the visual fantasy. Therefore, this direct involvement in a game may result in aggression (Silvern \& Williamson, 1987). Children who spend more time with gadget will be more at risk of being emotional or rebellious, because they feel they are being bullied when playing cool games. Smartphones give users access to a variety of applications, such as social media, music, and games where the latter is very popular with children. Games and children's films can actually take up a lot of children's time and this is evidenced by the opinion of David et al., (2015) that these various applications have different effects. 
Exposure to excessive smartphone or computer screens will adversely affect children (Twenge \& Keith Campbell, 2018). With children's disruption in playing with smartphones, they are likely to experience emotional discomfort and they can eventually act aggressively (Sultanbayeva, 2013; Bartholow \& Anderson, 2002). Children with a sufficient level of awareness may not care about the amount of time they spend playing with their gadgets. This is in line with what was stated by Lee et al. (2017) that individuals may lack awareness about the actual amount of time they spend on their devices.

Children who spend time using the development of technological gadgets are increasing rapidly especially with applications that are supported by the use of the internet (Strasburger, Jordan, \& Donnerstein, 2010). Internet applications offer a variety of programs that not only games but also the latest children's films that may make children addicted to see them repeatedly. This of course must be avoided because addiction in the early ages will greatly affect their future in further development. Therefore, the role of parents is very important in directing and controlling whenever their children can interact with their gadgets by giving understanding that they can accept.

Playing games and using the Internet seem to be at least potentially addictive (Griffiths, 2008). With regard to videogames, parents must be really smart in choosing which games can have an addictive effect, and which games that do not. In relation to gadgets with what children play games, children can access many different ways, including on handheld consoles, personal computers, home videogame consoles, arcade machines, the Internet, and other portable devices (for example, cellphones, i-Pods, etc). Therefore, this study has shown that research on video-games and internet addiction is a phenomenon that can affect children's development.

\section{CONCLUSION}

Gadgets can have an impact on children, especially when starting from an early age. This study shows that the use of gadgets, such as smartphones, in children is significantly related to children's development.

\section{REFERENCE}

Abdel-Aziz, A. A., Abdel-Salam, H., \& ElSayad, Z. (2016). The role of ICTs in creating the new social public place of the digital era. Alexandria Engineering Journal, 55(1), 487493. doi:10.1016/j.aej.2015.12.019

Zolfaghari Mashhadi, V., \& Reza Kargozari, M. (2011). Influences of digital classrooms on education. Procedia Computer Science, 3, 1178-1183. doi:10.1016/j.procs.2010.12.190

Blackwell, C. K., Lauricella, A. R., \& Wartella, E. (2014). Factors influencing digital technology use in early childhood education. Computers \& Education, 77, 82-90. doi:10.1016/j.compedu.2014.04.013

Alghamdi, Yasser. (2016). Negative Effects of Technology on Children of Today. doi: 10.13140/RG.2.2.35724.62089.

Phonkhao, N., \& (Laila), W. O. (2012). Social Structure and Early Childhood Learning Enhancement. Procedia - Social and Behavioral Sciences, 65, 225-231. doi:10.1016/j.sbspro.2012.11.115

Sundus, M. (2018). The Impact of using Gadgets on Children. J Depress Anxiety 7: 296. doi:10.4172/2167-1044.1000296

Cho, K.-S., \& Lee, J.-M. (2017). Influence of smartphone addiction proneness of young children on problematic behaviors and emotional intelligence: Mediating selfassessment effects of parents using smartphones. Computers in Human Behavior, 66, 303-311. doi:10.1016/j.chb.2016.09.063 
Chiu, C.-T., Chang, Y.-H., Chen, C.-C., Ko, M.-C., \& Li, C.-Y. (2015). Mobile phone use and health symptoms in children. Journal of the Formosan Medical Association, 114(7), 598-604. doi:10.1016/j.jfma.2014.07.002

Twenge, J. M., \& Keith Campbell, W. (2018). Associations between screen time and lower psychological well-being among children and adolescents: Evidence from a populationbased study. Preventive Medicine Reports. doi:10.1016/j.pmedr.2018.10.003

David, P., Kim, J.-H., Brickman, J. S., Ran, W., \& Curtis, C. M. (2014). Mobile phone distraction while studying. New Media \& Society, 17(10), 1661-1679. doi:10.1177/1461444814531692

Lee, H., Ahn, H., Nguyen, T. G., Choi, S.-W., \& Kim, D. J. (2017). Comparing the SelfReport and Measured Smartphone Usage of College Students: A Pilot Study. Psychiatry Investigation, $14(2), \quad 198$. doi:10.4306/pi.2017.14.2.198

Sultanbayeva, L., Shyryn, U., Minina, N., Zhanat, B., \& Uaidullakyzy, E. (2013). The Influence of Computer Games on Children's Aggression in Adolescence. Procedia - Social and Behavioral Sciences, 82, 933-941. doi:10.1016/j.sbspro.2013.06.374

Bartholow, B. D., \& Anderson, C. A. (2002). Effects of Violent Video Games on Aggressive Behavior: Potential Sex Differences. Journal of Experimental Social Psychology, 38(3), 283-290. doi:10.1006/jesp.2001.1502

Silvern, S. B., \& Williamson, P. A. (1987). The effects of video game play on young children's aggression, fantasy, and prosocial behavior. Journal of Applied Developmental Psychology, 8(4), 453-462. doi:10.1016/01933973(87)90033-5

Strasburger, V. C., Jordan, A. B., \& Donnerstein, E. (2010). Health Effects of Media on Children and Adolescents. PEDIATRICS, 125(4), 756-767. doi:10.1542/peds.2009-2563
Hosokawa, R., \& Katsura, T. (2018). Association between mobile technology use and child adjustment in early elementary school age. PLOS ONE, 13(7), e0199959. doi:10.1371/journal.pone.0199959

Griffiths, M. (2008). Internet and video-game addiction. Adolescent Addiction, 231-267. doi:10.1016/b978-012373625-3.50010-3 